\title{
Makna Female Masculinity dalam Kostum Wayang Srikandi Red Batik Solo
}

\author{
Farah Nur Azizah, Yudha Wirawanda \\ Universitas Muhammadiyah Surakarta \\ J1. A. Yani, Mendungan, Pabelan, Kec. Kartasura, Kabupaten Sukoharjo, Jawa Tengah 57162 \\ farahazizah.zzz@gmail.com, yudha.wirawanda@ums.ac.id
}

Masuk tanggal : 17-10-2018, revisi tanggal : 21-05-2019, diterima untuk diterbitkan tanggal : 11-07-2019

\begin{abstract}
This research is a study about the meaning of female masculinity in fashion. The object of analysis is the Javanese figure, Dewi Srikandi in the Red Batik Solo Costume Carnival. This Javanese figure, Dewi Srikandi is interesting to study because she has strong myths about masculinity. Beside that, the researcher also interested in how this female warrior figure looks masculine which is observed from the costumes and accessories worn. The purpose of this study is to find out how does Dewi Srikandi gives the meaning by the costume into the visual of the Red Batik Solo carnival. The analysis uses semiotics Roland Barthes with a qualitative approach and the theory of Female Masculinity Halberstam. The analysis shows that Srikandi is a female character or role that has masculine characteristics that can be observed from analysis of the color, meaning of denotation and connotation and also meaning of myth, such as red, black, white, brown and dark colors. Masculine also can be shown from Srikandi costumes which are related with syntagmatic and paradigmatic, such as red can be replaced with dark colors (black or brown). In addition, costume accessories such as ricikan (crown, sumping, necklace, bracelet, belt or belt, arrow, and shoes) also give masculine meaning which are indicated by the characteristics of masculine generally, for example strength, courage, aggressiveness, leadership, assertiveness, domination, and violence.
\end{abstract}

Keywords: fashion, masculinity, roland barthes, semiotics, srikandi,

\begin{abstract}
Abstrak
Penelitian ini menganalisis mengenai makna Female Masculinity. Objek penelitian ini pada kostum wayang Srikandi yang dibuat oleh Red Batik Solo. Tokoh wayang Jawa Dewi Srikandi ini menarik untuk diteliti karena mempunyai mitos yang kuat tentang karakter wanita yang memiliki sisi maskulin. Tujuan dari penelitian ini adalah untuk mengetahui bagaimana makna yang disampaikan Dewi Srikandi kedalam bentuk visual fashion kostum karnaval Red Batik Solo. Analisis yang digunakan adalah analisis semiotika oleh Roland Barthes dengan pendekatan kualitatif dan teori Female Masculinity Halberstam. Selain itu, peneliti juga tertarik tentang bagaimana tokoh prajurit wanita ini terlihat maskulin yang diamati dari kostum dan aksesoris yang dikenakan. Hasil analisis menunjukkan bahwa Srikandi adalah tokoh puteri yang memiliki sifat maskulin yang dapat diamati dari analisis warna, makna denotasi dan konotasi serta makna mitos, seperti warna merah, hitam, putih, coklat dan warna gelap. Sifat maskulin juga dapat ditunjukkan dari kostum Srikandi yang dihubungkan dengan sintagmatik dan paradigmatik, seperti warna merah dapat diganti dengan warna gelap (hitam atau coklat). Selain itu, aksesoris kostum seperti ricikan (mahkota, sumping,
\end{abstract}


kalung, gelang, ikat pinggang atau sabuk, panah, dan sepatu) juga memberi makna maskulin yang ditunjukkan dari karakteristik yang umumnya dianggap maskulin, misalnya menunjukkan kekuatan, keberanian, agresivitas, kepemimpinan, ketegasan, dominasi, dan kekerasan.

Kata Kunci: fashion, maskulinitas, Roland Barthes, semiotika, Srikandi

\section{Pendahuluan}

Red Batik Solo merupakan salah satu komunitas yang menghasilkan fashion kostum karnaval. Buku Direktorat Jendral Ekonomi Kreatif Berbasis Seni Dan Budaya terbitan Kementrian Komunikasi dan Informasi (2014) menjelaskan, Red Batik Solo adalah sebuah komunitas anak muda kota Solo yang berkreativitas dengan membuat sebuah rancangan kostum karnaval. Red Batik Solo berdiri pada 12 Februari 2011. Komunitas ini, berkreativitas dengan menggunakan bahan-bahan alam yang ramah lingkungan, bahan alam yang sudah tersedia di pasar tradisional maupun dilingkungan sekitar. Selain bahan alam tradisional, Red Batik Solo juga menggunakan kain batik sebagai salah satu bahan untuk lebih menekankan sebuah karya yang tradisional serta mengangkat budaya Jawa yang dijadikan sebagai warisan budaya Indonesia.

Budaya dalam culture studies didefinisikan sebagai objek keadiluhungan estetis (seni tinggi). Budaya dipahami sebagai teks dan praktik hidup sehari-hari (Storey, 1996). Dalam kompleksitas perkembangan yang ada dimasyarakat menunjukkan kebudayaan memiliki keterkaitan yang sangat erat dalam representasi (penciptaan makna) sekaligus menjelaskan posisi suatu kelompok sosial atau individu didalam struktur sosial (Storey, 1996). Peneliti mengambil tokoh wayang Srikandi untuk dijadikan sebagai subjek penelitian. Produk tersebut adalah sebuah rancangan fashion kostum karnaval yang mengambil tokoh wayang Dewi Srikandi pada budaya Jawa terkhusus budaya wayang di Surakarta. Produk kostum karnaval bertemakan Dewi Srikandi dirancang untuk menyambut acara Konferensi Asia Afrika di Bandung dengan tujuan memperkenalkan budaya Jawa. Budaya Jawa merupakan pancaran budi manusia Jawa yang mencakup kemauan, cita-cita, ide dan semangat dalam mencapai kesejahteraan, keselamatan dan kebahagiaan hidup lahir batin (Endraswara, 2005). Kebudayaan sebagai latar belakang praktik, representasi, bahasa, dan adat kebiasaan masyarakat historis tertentu (Rusdy, 2015).

Tokoh wayang Dewi Wara Srikandi yang sering dikenal dengan Srikandi adalah seorang tokoh wayang yang mempunyai ilmu keprajuritan. Ia juga sebagai ikon prestasi bagi wanita indonesia apabila terdapat wanita indonesia yang kuat dan dapat menyelesaikan tugasnya dengan baik, mereka di gadang-gadang sebagai Srikandi (Solichin, 2016). Srikandi, istri Arjuna ialah tokoh wayang yang digambarkan identik dengan kelelakiannya, dan dikenal sebagai prajurit atau pahlawan wanita (Hardjowirogo, 1989). Dewi Srikandi memiliki karakter tokoh sebagai seorang dewi yang kuat, yang mahir dalam memanah, dan sebagai ksatria pahlawan wanita dalam pewayangan Jawa (Solichin, 2016). Srikandi identik dengan kelelakiannya sehingga menggambarkankan sifat maskulin pada tubuh wanita. Maskulin adalah sifat 
Farah Nur Azizah, Yudha Wirawanda : Makna Female Masculinity dalam Kostum Wayang Srikandi Red Batik Solo

yang melekat pada tubuh laki-laki. Maskulinitas pada laki-laki tidak hanya memperlihatkan dari segi kekuatan dan cara laki-laki berdandan, namun juga dapat dilihat dari cara berpakaian (fashion) mereka yang menunjukkan sifat maskulin (Yulianti, Bajari, \& Mulyana, 2017)

Ketika membahas mengenai fashion dan pakaian sebagai artefak budaya, hal ini membawa pada sebuah kajian semiotika yaitu semiotika objek. Semiotika objek mengkaji mengenai reproduksi makna pada bentuk-bentuk visual objek budaya dan objek-objek alam (Barnard, 2011). Barthes dalam The Fashion System, melakukan suatu percobaan untuk menetapkan metode dalam analisis mode pakaian wanita (Barthes, 1983). Barthes memperlihatkan bahwa di belakang fashion terdapat suatu sistem. Fashion bisa dilihat sebagai suatu sistem bahasa yang memiliki makna. Barthes berpendapat, untuk mempermudah dalam menganalisis mode ia menggunakan formula sederhana atau sebuah istilah matriks. Mode dapat dijelaskan melalui istilah matriks dari sebuah objek penanda (O), dukungan (S), dan varian (V) (Barthes, 1983). Selain melakukan percobaan analisis struktural pada mode pakaian wanita, Barthes juga memunculkan konsep guna menjelakan hal-hal yang berkaitan dengan mitos, dan relasi makna denotatif maupun konotatif. Barthes menjelaskan pemikirannya tentang tanda melaui kajian mitos. Mitos menurut Barthes merupakan suatu pengungkapan dan pembenaran untuk nilai-nilai dominan yang berlaku dalam periode tertentu (Sobur, 2016)

Penelitian serupa yang juga menggunakan fashion sebagai bahan kajiannya juga sudah pernah dilakukan. Penelitian serupa yang pertama berjudul Fashion as communication: A semioticanalysis of fashion on 'Sex and the City'oleh Katarina Kuruc (2008) yang merupakan analisis wacana semiotika Saussure. Dalam penelitiannya menunjukkan peran fenomenal bahwa fashion sebagai bentuk komunikasi yang dimainkan dalam masyarakat kontemporer khususnya dimedia televisi. Penelitian tersebut berfokus pada empat karakter wanita berbeda. Perbedaan dalam penelitian ini terletak pada metode dan subjek yang digunakan. Penelitian terdahulu menggunakan metode semiotika Saussure untuk menganalisis subjek fashion on sex and the city dalam sebuah acara televisi. Sedangkan persamaan dengan artikel ini terletak pada sebuah penelitian semiotika visual fashion sebagai bentuk komunikasi yang dimainkan dalam bentuk kontemporer.

Penelitian serupa yang kedua berjudul An Analysis Of Female Masculinity In Ousmane Sembene's God's Bits Of Wood oleh Edward Mooka (2016) merupakan analisis wacana yang menggunakan teori performatif Judith Butler, teori Judith Halberstam (1998) tentang maskulinitas perempuan, serta argumen Lindsay dan Miescher untuk memunculkan representasi maskulinitas perempuan dalam novel Sembene. Penelitian tersebut mendefinisikan maskulinitas perempuan sebagai kinerja maskulinitas pada tubuh perempuan yang mengambil perilaku atau karakteristik yang dianggap maskulin, misalnya menunjukkan kekuatan, keberanian, agresivitas, kepemimpinan, ketegasan, dominasi, dan kekerasan (Abele, 2003 dalam Mooka, 2016). Perbedaan dalam penelitian ini terletak pada metode dan subjek yang digunakan. Pada artikel ini menggunakan analisis wacana untuk menganalisis maskulinitas pada novel 
Sembene Ousmane, sedangkan persamaan dengan artikel ini terletak pada menganalisis mengenai maskulinitas wanita dengan menggunakan teori Female Masculinity dari Judith Halberstam (1998). Teori Female Masculinity ini digunakan sebagai pendukung teori dalam menganalisis semiotika pada kostum Srikandi budaya Jawa.

Budaya wayang sangat erat dengan kehidupan budaya Jawa, sehingga tanda-tanda dan kode-kode semiotika Jawa menjadi sangat kental dirasakan. Wayang tidak hanya berisikan mitos (masa lalu), namun berkembang sepanjang zaman karena tokoh-tokoh pewayangan yang ditampilkan mewakili karakter asli dalam kehidupan manusia, seperti loyalitas, kejujuran, sikap ksatria, keculasan, kedengkian, ketamakan, dan lain sebagainya merupakan sebagian dari karakter manusia yang dibicarakan dalam dunia pewayangan. Hal tersebut dijadikan sebagai upaya untuk memudahkan melihat lebih mendalam mengenai pemikiran semiology dan semiotika dalam wayang (Rusdy, 2015).

Berdasar uraian di atas, peneliti tertarik pada Dewi Srikandi yang dijadikan tema dalam kostum karnaval Red Batik Solo. Seorang desainer kostum karnaval Red Batik Solo menghasilkan karya kostum karnaval yang mengacu pada bentuk artistik dan praktik representasi dari tokoh Wayang Srikandi dalam rancangan kostum. Tokoh Wayang Jawa Srikandi menarik untuk diteliti karena mempunyai mitos yang kuat tentang maskulinitas wanita. Maskulinitas wanita menurut Halberstam (1998), menganggap bahwa wanita sebagai kategori dalam hal gender, yaitu pria atau wanita, sedangkan maskulin sebagai kriteria yang tampak seperti peran, kepribadian, dan pengalaman. Berangkat dari pemaparan tersebut, maka peneliti merasa perlu untuk meneliti bagaimana makna Female Masculinity dalam kostum Srikandi.

\section{Metode Penelitian}

Penelitian ini, menggunakan metode analisis semiotika oleh Roland Barthes. Metode tersebut dipilih karena Roland Barthes memiliki kajian khusus mengenai fashion. Penelitian ini meneliti dengan cara memaparkan dan menjelaskan dengan menggunakan pendekatan kualitatif dari data-data pengamatan, wawancara serta dokumen-dokumen yang sudah tersedia (Rakhmat, 2005).

Penelitian ini menggunakan jenis data Primer, yaitu data yang diperoleh dari dokumentasi yang relevan, berupa catatan-catatan, surat kabar, arsip, laporan, dan foto-foto (Pujileksono, 2015). Dokumen dan arsip laporan baik dari internal atau eksternal komunitas, referensi yang mendukung penelitian yang pernah dilakukan sebelumnya dan foto-foto yang mendokumentasikan event yang diikuti Red Batik Solo. Pada penelitian ini menggunakan dokumen-dokumen foto Red Batik Solo ketika berpartisipasi dalam event Konferensi Asia Afrika 2015 di Bandung.

Teknik pengambilan sampel dalam penelitian menggunakan purposive sampling yang disesuaikan pada kriteria-kriteria tertentu yang diterapkan berdasarkan tujuan penelitian dengan jenis sampel frame yang sudah tersedia (Husaini dan Purnomo, 2014). Peneliti mengambil tiga subyek kostum tokoh 
wayang Srikandi karnaval Red Batik Solo menganalisis bagian pakaian, dan aksesoris (mahkota, sumping, kalung, gelang, ikat pinggang atau sabuk, panah, dan sepatu). Unit analisis menggunakan foto-foto kostum karnaval yang dipisahkan pada setiap bentuk bagian-bagian dalam kesatuan kostum. Peneliti menggunakan sistem formula Barthes seperti pada karyanya The Fashion System yaitu menggunakan formula atau matriks VOS (Variant, Objek, Support) dengan teknik analisis denotasi, konotasi, dan mitos (Barthes, 1983). Objek merupakan suatu bentuk tanda objek secara keseluruhan, support sebagai bagian pendukung dalam objek, sedangkan variant sebagai sesuatu yang tidak dapat dijumpai pada pendukung yang sama sehingga membentuk kelompok pragmatik (Barnard, 2011).

Metode analisis data pada penelitian ini menggunakan semiotika Roland Barthes yang bertujuan untuk mengetahui makna tanda pada kostum karnaval Red Batik Solo yang mengambil Tokoh Wayang Srikandi sebagai tema kostum. Analisis semiotika Roland Barthes memfokuskan pada gagasan mengenai two order of signification atau tentang signifikasi dua tahap. Signifikasi pada tahap pertama merupakan hubungan antara penanda (signifier) dan petanda (signified), yang disebut denotasi oleh Barthes (Sobur, 2016). Pada tahap pertama ini merupakan makna yang harfiah atau makna yang sesungguhnya dari suatu istilah atau citra (Barnard, 2011). Sedangkan signifikasi tahap kedua merupakan makna yang dihasilkan akibat dari usia, kelas, jenis kelamin dan kebudayaan tertentu yang memiliki konsekuensi bisa berubah-ubah dari satu orang ke orang lain (Barnard, 2011). Signifikasi tahap kedua ini disebut konotasi oleh Barthes (Sobur, 2016). Dalam kerangka Barthes, konotasi identik dengan operasi ideologi yang disebutnya sebagai mitos. Mitos bagi Barthes berfungsi untuk memberikan pembenaran terhadap nilai-nilai dominan yang berlaku dalam periode tertentu (Sobur, 2016).

Validitas data pada penelitian ini menggunakan triangulasi yang memanfaatkan data dari suatu sumber kemudian peneliti mengoreksi dengan sumber lain untuk mengkonfirmasi dan sebagai pembanding data tersebut (Pujileksono, 2015). Pada kegiatan penelitian ini, teknik triangulasi yang digunakan adalah teknik triangulasi teori dengan memanfaatkan dua atau lebih teori untuk diadu atau dipadu.

\section{Hasil Penemuan dan Diskusi}

Untuk menganalisis maskulinitas wanita dalam kostum karnaval Red Batik Solo pada tokoh wayang Srikandi, peneliti melakukan koding pada ketiga foto kostum yang bertemakan Srikandi. Analisis ini dilakukan dengan menggunakan teori semiotika Roland Barthes seperti yang sudah dipaparkan peneliti pada metode penelitian di atas. Dalam menganalisis kostum, peneliti membagi dalam tiga kategorisasi yang menunjukkan female masculinity.

Peneliti menganalisis kostum Srikandi I, II, dan III dengan menggunakan metode Variant, Obyek, dan Support. Bagian dari kostum yang dianalisis adalah mahkota, Sumping, kalung, gelang, pakaian, rok, panah yang terdiri dari anak panah dan busur beserta, ikat pinggang atau sabuk dan sepatu. 


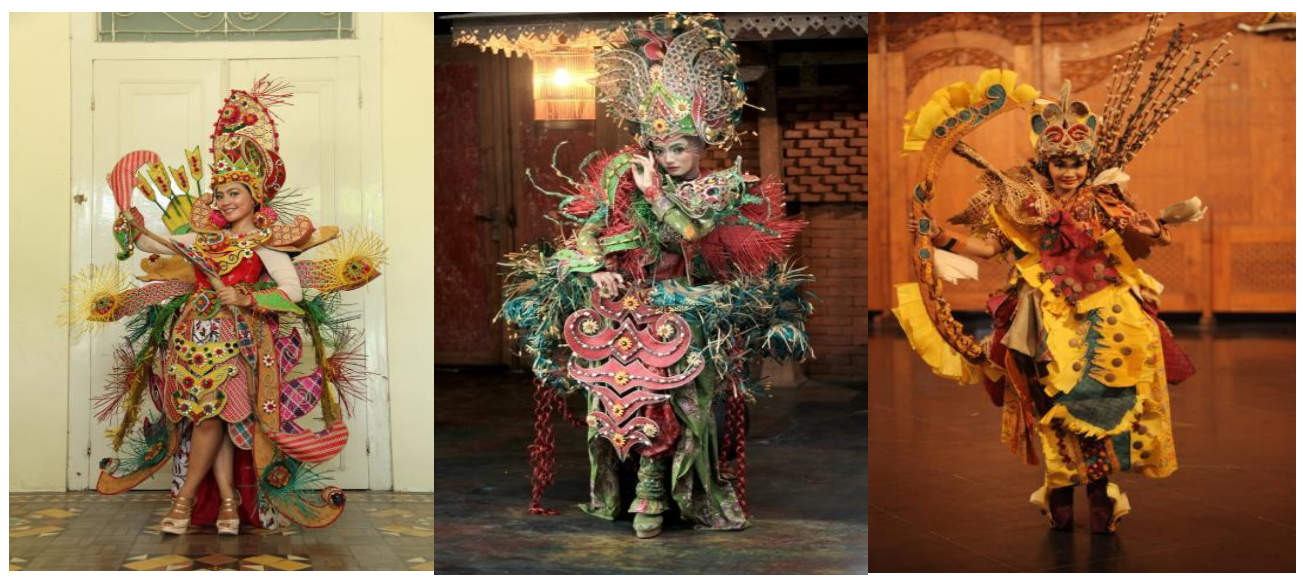

Gambar 1: Kostum I, II, dan III yang dianalisis

\section{Warna dan Female Masculinity}

Tabel 1. Analisis Denotatif-Konotatif Pakaian Atas Kostum Srikandi I

\begin{tabular}{|c|c|}
\hline Sr Denotatif & Sd Denotatif \\
\hline $\begin{array}{l}\text { Pakaian manset warna coklat susu dan } \\
\text { kemben warna merah dengan motif } \\
\text { bunga. }\end{array}$ & $\begin{array}{l}\text { Objek : Manset dan kemben } \\
\text { Variant: Warna merah dan coklat } \\
\quad \text { susu. } \\
\text { Support: Motif bunga pada kemben. } \\
\text { Manset berwarna coklat susu polos } \\
\text { lengan panjang dan dilengkapi kemben } \\
\text { merah terang bermotif bunga dikenakan } \\
\text { oleh tokoh dalam event Konferensi Asia } \\
\text { Afrika } 2015 \text { di Bandung. }\end{array}$ \\
\hline Sr Konotatif & Sd Konotatif \\
\hline $\begin{array}{l}\text { Pakaian Srikandi berupa kain semekan } \\
\text { atau kemben. }\end{array}$ & $\begin{array}{l}\text { Objek : Semekan atau Kemben dan } \\
\quad \text { Manset } \\
\text { Variant: Warna merah } \\
\text { Support: Motif bunga pada kemben. } \\
\text { Manset yang dikenakan berwarna coklat } \\
\text { susu polos menandakan warna kulit } \\
\text { Srikandi yang bersih dan halus, lengan } \\
\text { panjang menandakan kesopanan dalam } \\
\text { berpakaian tanpa menunjukkan aurat } \\
\text { wanita, warna merah terang bermotif } \\
\text { bunga menandakan Srikandi wanita kuat } \\
\text { serta maskulin (Nuraini, 2011). }\end{array}$ \\
\hline
\end{tabular}

Mekak merupakan busana khusus untuk penari putri, berbentuk menyerupai kemben (kain penutup dada pada busana tradisional Jawa). Dipakai dari dada sampai ke pinggang yang dilengkapi dengan bokongan/penutup bokong sebagai penutup badan bagian atas. Peran pokok biasanya memakai mekak dari 
Farah Nur Azizah, Yudha Wirawanda : Makna Female Masculinity dalam Kostum Wayang Srikandi Red Batik Solo

bahan beludru, sedangkan untuk peran bala dipakai bahan dasar kain satin (Nuraini, 2011). Mekak berwarna merah menandakan kekuatan, sesuai dengan pernyataan Hyman (2006), yang menyatakan bahwa warna dapat berupa kekuatan yang tidak bisa dilihat seperti warna merah. Warna merah menurut Johnson (2010), diartikan sebagai warna darah yang berhubungan dengan perang. Perang berarti kekuatan yang menandakan maskulinitas, hal ini sesuai dengan pernyataan Paechter (2006), bahwa kekuatan menunjukkan maskulinitas tidak hanya untuk laki-laki tetapi juga pada wanita. Berdasarkan uraian tersebut, maka dapat disimpulkan bahwa Mekak Srikandi memiliki makna maskulinitas dilihat dari warna merah yang menandakan kekuatan.

Kostum dapat dilihat dari denotasi dan konotasinya, warna hitam, merah, kuning, hijau, coklat, dan ungu memiliki makna masing-masing. Hitam adalah tanda kegelapan, karena dapat menyerap semua energi dari warna lain dan tidak adanya cahaya, tidak ada panjang gelombang yang dipantulkan. Bleicher (2012), menyatakan warna hitam dan putih adalah maskulin, sementara warna lainnya adalah warna feminin. Hal ini sesuai dengan makna warna hitam yaitu perang di negara Amerika Selatan, khususnya pada suku Aztec. Perang berarti kekuatan yang menandakan maskulinitas. Paechter (2006) mengatakan, bahwa kekuatan menunjukkan maskulinitas tidak hanya untuk laki-laki tetapi juga pada wanita. Plato dalam Kiefer (2003) menyatakan, warna merah memiliki arti api dan menyerupai darah. Warna merah menurut Johnson (2010), diartikan sebagai warna darah yang berhubungan dengan perang. Menurut Sain (2018), beberapa penduduk asli Amerika dan Kanada menggunakan warna merah dalam upacara dan perang. Perang berarti kekuatan yang menandakan maskulinitas. Warna kuning adalah warna kreatifitas, dan percaya diri yang menandakan kepercayaan dan optimisme (Johnson, 2010). Menurut Sain (2018), warna kuning di Amerika Serikat berhubungan dengan bunga Lili yang bermakna pusat keberanian pada hati. Keberanian menandakan maskulinitas, hal tersebut sesuai dengan pernyataan Mooka (2016) yang menyatakan bahwa maskulinitas wanita dilihat dari kinerja atau perilaku maskulin pada tubuh wanita yang karakteristik umumnya dianggap maskulin misalnya, menunjukkan kekuatan, keberanian, agresivitas, kepemimpinan, ketegasan, dominasi, dan kekerasan.

Pada kostum kedua didominasi warna hijau. Warna hijau adalah warna keseimbangan, penyegaran, cinta universal, istirahat, pemulihan, jaminan, kesadaran lingkungan, keseimbangan, kedamaian, dan kebosanan (Johnson, 2010). Warna hijau menurut Bleicher (2012) menandakan bahaya dan kematian pada masyarakat Amerika Selatan yang masih tinggal di kawasan hutan lebat. Bahaya identik dengan pekerjaan militer dalam tugasnya dalam berperang, Kachtan dan Varda (2015). Perang identik dengan kekuatan yang menandakan maskulinitas. Kekuatan menunjukkan maskulinitas tidak hanya untuk laki-laki tetapi juga pada wanita (Paechter, 2006).

Pada kostum ketiga dominan dengan warna coklat. Menurut Johnson (2010), warna coklat terbentuk dari percampuran merah dan kuning, yang menandakan keseriusan, tetapi lebih hangat dan lebih lembut dan juga bersifat menekan, bukannya mendukung. Warna coklat mampu membangkitkan kekuatan dan keandalan, serta berkaitan dengan bumi seperti kayu dan batu sehingga dapat 
menimbulkan tanggapan yang menganggapnya kotor. Kotor menandakan maskulinitas, sesuai dengan pernyataan Kachtan dan Varda (2015), tentara atau militer yang profesional menandakan sifat maskulin yaitu ditandai dengan kotor, agresif dan garang dalam peperangan.

Pada kostum pertama terdapat warna violet. Warna dengan panjang gelombang terpendek disebut sebagai warna ungu yang menunjukkan adanya sensasi spiritual. Dibutuhkan tingkat pemikiran yang tinggi untuk mendorong untuk meditasi seperti adanya sinar ultraviolet yang memiliki asosiasi dengan waktu dan ruang kosmos (Johnson, 2010).

Srikandi adalah tokoh wayang yang memiliki ilmu keprajuritan. Selain itu, Srikandi dijadikan sebagai ikon prestasi wanita di Indonesia. Apabila terdapat wanita yang dapat menyelesaikan tugasnya dengan baik, berani dan kuat maka mereka dijuluki sebagai Srikandi. Srikandi memiliki karakter maskulin yang dapat dilihat dari peran dalam pewayangan Jawa. Karakter maskulin dalam kostum Srikandi dapat dilihat dari tanda-tanda maskulin, seperti warna-warna yang dilihat dari makna konotatif dan makna mitos. Peneliti menganalisis warna yang menandakan maskulinitas sesuai dengan makna konotatif dan mitos warna maskulin yang telah dianalisis oleh para ahli sebelumnya, yang selanjutnya dijadikan sebagai referensi peneliti.

\section{Aksesoris kostum sebagai penguat Female Masculinity Panah Srikandi}

Tabel 2. Analisis Denotatif-Konotatif Panah Kostum Srikandi II

\begin{tabular}{|c|c|}
\hline Sr Denotatif & Sd Denotatif \\
\hline $\begin{array}{l}\text { Busur panah terbuat dari rotan dengan } \\
\text { bagian tengahnya diberikan hiasan } \\
\text { anyaman warna hijau dan merah, serta } \\
\text { ujung busur diberikan aksen dari lidi } \\
\text { bambu dikombinasikan biji-bijian } \\
\text { berwarna merah diujungnya, serta } \\
\text { bagian belakang terdapat anyaman } \\
\text { berwarna merah dengan ujung terdapat } \\
\text { biji-bijian berwarna kuning yang } \\
\text { menempel. }\end{array}$ & $\begin{array}{l}\text { Objek : } \begin{array}{r}\text { Busur panah dan anyaman } \\
\text { bambu }\end{array} \\
\text { Variant: Warna merah, kuning, dan } \\
\text { hijau. } \\
\text { Support: Anyaman dan motif biji-bijian. } \\
\text { Busur panah terlihat kuat karena berbahan } \\
\text { dasar rotan yang terkenal dengan } \\
\text { kekokohannya, dibagian tengah terdapat } \\
\text { anyaman berwarna merah dan hijau yang } \\
\text { dapat mempercantik tampilan busur } \\
\text { sehingga tidak terlihat pucat, ujung busur } \\
\text { tampak indah, mewah dan elegan karena } \\
\text { terdapat kumpulan seperti putik bunga } \\
\text { yang makin memperindah tampilan, } \\
\text { anyaman dibagian punggung tampak cerah } \\
\text { dan meriah ketika dikenakan oleh tokoh } \\
\text { dalam event Konferensi Asia Afrika } 2015 \\
\text { di Bandung. }\end{array}$ \\
\hline Sr Konotatif & Sd Konotatif \\
\hline $\begin{array}{l}\text { Panah Srikandi memiliki busur panah } \\
\text { yang besar dan kuat serta } \\
\text { dikombinasikan dengan }\end{array}$ & $\begin{aligned} & \text { Objek : Panah yang terdiri dari anak } \\
& \text { panah dan busur panah. } \\
& \text { Variant : Warna merah, hijau dan }\end{aligned}$ \\
\hline
\end{tabular}


Farah Nur Azizah, Yudha Wirawanda : Makna Female Masculinity dalam Kostum Wayang Srikandi Red Batik Solo

$\begin{aligned} \text { dan anak panah berwarna merah terang. } & \begin{array}{c}\text { kuning. } \\ \text { Support }: \text { Anyaman dan motif dari biji- } \\ \text { bijian. }\end{array} \\ & \begin{array}{l}\text { Panah menunjukkan sifat maskulin, bahan } \\ \text { dasar rotan yang menandakan bahwa }\end{array} \\ & \text { badan busur sangat kuat dengan pangkal } \\ & \text { anak panah berwarna kuning menandakan } \\ & \text { kejayaan dan keberanian, anak panah } \\ & \text { berwarna merah menandakan api yang } \\ & \text { membara, (Nuraini, 2011), serta ujungnya } \\ & \text { diberi aksen biji-bijian berwarna kuning } \\ & \text { menandakan anak panah tajam dan runcing } \\ & \text { sebuah busur besar dengan motif anyaman } \\ & \text { merah dan hijau di tengah dan } \\ & \text { menandakan keberanian atau maskulinitas } \\ & \text { dan ketenangan, (Mooka, 2016). }\end{aligned}$

Panah Sengkali menunjukkan sifat maskulin pada tokoh Srikandi yang sesuai dengan mitos tabiat Srikandi sebagai tabiat laki-laki, gemar pada peperangan, karena itu Srikandi disebut putri prajurit. Dalam peperangan Baratayudha Srikandi diangkat menjadi panglima perang melawan Bisma. Srikandi menggunakan panah sakti Sengkali sebagai senjatanya dalam berperang, (Soffiyana, 2015). Berdasarkan penjelasan tersebut, bahwa panah merupakan senjata yang digunakan Srikandi untuk berperang, sehingga dapat dinyatakan bahwa panah Srikandi menandakan maskulinitas, hal ini sesuai dengan pernyataan Mankayi (2008) yang menyatakan bahwa senjata adalah suatu alat atau kunci dari maskulinitas. Orang sipil dengan seragam tentara dan senjata menjadi penentuan dominan dalam membentuk sisi maskulinitas.

Aksesoris yang dikenakan pada kostum Srikandi I, II, dan III meliputi mahkota, sumping, kalung, gelang, ikat pinggang atau sabuk, panah, dan sepatu. Pada mahkota Srikandi I dan Srikandi II berbentuk Pogog Ageng biasa digunakan oleh peran adipati atau patih, misalnya Dhuryudana. Srikandi III menggunakan mahkota dengan irah-irahan Gelung Keling yang biasa digunakan oleh puteri sesuai dengan karakternya. Srikandi I, Srikandi II, dan Srikandi III mempunyai bentuk Jamang lancip atau cringih. Jamang berbentuk cringih atau runcing digunakan oleh peran yang lanyak atau branyak (Nuraini, 2011). Berdasarkan dari penjelasan tersebut, maka dapat disimpulkan bahwa Srikandi memiliki sisi maskulinitas dilihat dari bentuk jamang cringih atau runcing yang biasa dikenakan oleh seorang ksatria, dan tokoh putra gagah yang memiliki kekuatan, hal ini sesuai dengan pernyataan Mooka (2016) yang menyatakan bahwa kekuatan merupakan karakter maskulin.

Sumping merupakan aksesoris pada pakaian wayang yang letaknya pada daun telinga. Sumping difungsikan sebagai penjepit agar mahkota atau jamang lebih kuat ketika dikenakan. Menurut Nuraini (2011), jenis sumping ada sumping Surengpati, sumping Waderan, sumping Bunga Kluwih, sumping Pudak Sinumpet, sumping Gajah Oling, sumping Bunga Pacar dan sumping Bunga Telekan. Srikandi I dan Srikandi II menggunakan jenis sumping Pudak Sinumpet, 
Srikandi III menggunakan jenis sumping Waderan. Meskipun berbeda jenis, namun Srikandi I, Srikandi II dan Srikandi III menggunakan sumping yang berbentuk cringih atau lancip digunakan oleh peran yang lanyak atau branyak (Nuraini, 2011).

Sumping Pudak Sinumpet adalah sumping yang dikenakan Werkudara di telinganya (Nuraini, 2011). Bentuknya seperti gajah yang sedang berguling, dihiasi bunga pudhak berwarna putih dan harum baunya. Berdasarkan bentuk sumping yang biasanya dipakai oleh prajurit, maka dapat dinyatakan bahwa Srikandi memiliki sisi maskulinitas. Hal ini sesuai dengan pernyataan Parvathi, (2017) yang menyatakan bahwa maskulinitas itu menggambarkan tentang kekuatan, agresifitas dan kejantanan pada tubuh wanita.

Kalung merupakan aksesoris yang dikenakan dibagian leher. Menurut Sekar Budaya Nasional (2011), kalung berbentuk wulan tumanggal (bulan sabit), satu atau dua susun melingkar di leher sampai batas dada menandakan seorang ksatria. Berdasarkan penjelasan tersebut, maka dapat disimpulkan bahwa Srikandi I memiliki sifat maskulin, karena ksatria sangat identik dengan laki-laki. Hal ini sesuai dengan pernyataan Hajariah dan Rizki (2013) yang menyatakan bahwa aksi pahlawan mengacu pada peran yang biasanya dimainkan oleh lakilaki dengan alasan bahwa karya fiksi hanya mengakui laki-laki untuk memainkan peran itu. Namun, sekarang sudah banyak yang menjadikan wanita sebagai pahlawan yang berkarakter kuat dan tajam, yang menujukkan sisi maskulin.

Srikandi II menggunakan kalung berbentuk bulat dengan lubang di tengah dikelilingi dengan rumbai-rumbai cringih. Kalung berwarna merah menyala di bagian tengah, menandakan api yang membara. Sesuai dengan pernyataan Plato dalam Kiefer (2003) yang menyatakan bahwa warna merah memiliki arti api dan menyerupai darah. Warna merah menurut Johnson (2010), juga diartikan sebagai warna darah yang berhubungan dengan perang. Perang berarti kekuatan yang menandakan maskulinitas, hal ini sesuai dengan pernyataan Paechter (2006), bahwa kekuatan menunjukkan maskulinitas tidak hanya untuk laki-laki tetapi juga pada wanita. Berdasarkan uraian tersebut, maka dapat disimpulkan bahwa kalung Srikandi memiliki makna maskulinitas dilihat dari warna merah yang menandakan darah dan kekuatan api.

Srikandi I dan Srikandi II menggunakan gelang jenis Calumpringan yang memiliki bentuk lancip. Gelang tangan Calumpringan biasa digunakan oleh tokoh raja atau kesatria yang kedudukannya setara dengan raja merupakan filosofi dari seorang raja yang melindungi rakyatnya (Sunu, 2012). Kedudukan sebagai raja dan ksatria menandakan sisi maskulin pada Srikandi. Hal ini sesuai dengan pernyataan Paechter (2006), yang menyatakan bahwa maskulinitas adalah apa yang dilakukan laki-laki dewasa dan anak laki-laki, misalnya laki-laki yang tertarik dengan kekuatan. Sedangkan Srikandi III menggunakan bentuk gelang menyerupai bentuk gelang logam yang biasa digunakan oleh putera (Nuraini, 2011). Berdasarkan penjelasan tersebut, maka dapat disimpulkan bahwa Srikandi III memiliki sifat maskulin dilihat dari aksesoris gelang logam yang biasa dikenakan oleh seorang laki-laki dalam pewayangan. 
Farah Nur Azizah, Yudha Wirawanda : Makna Female Masculinity dalam Kostum Wayang Srikandi Red Batik Solo

Pada bagian pinggang, kostum Srikandi I, II, dan III mengenakan sabuk. Sabuk menandakan sifat maskulin, tokoh Srikandi I mengenakan jenis aksesoris Slepe. Slepe berfungsi sebagai ikat pinggang untuk perlengkapan busana tari putri dan dipakai setelah memakai sampur atau selendang, (Nuraini, 2011). Sabuk atau ikat pinggang yang dikenakan oleh Srikandi, menandakan maskulinitas, karena sabuk atau ikat pinggang identik dengan laki-laki. Hal ini sesuai dengan pernyataan Mankayi (2008) yang menyatakan bahwa laki-laki lebih sering dan melihat bagaimana membuat dasi, bagaimana memakai sepatu, bagaimana cara berpakaian, bagaimana memakai celana dan ikat pinggang dan semua jenisnya.

Srikandi II dan Srikandi III yang memiliki sifat aktif yang disegani, energetik, dan ambisius, menggunakan Lonthon Cinde/Stagen yang digunakan sebagai sabuk (Supriyono, 2008). Sabuk warna merah, menandakan api. Plato dalam Kiefer (2003), menyatakan bahwa warna merah memiliki arti api dan menyerupai darah. Warna merah menurut Johnson (2010), warna darah berhubungan dengan perang, perang berarti kekuatan yang menandakan maskulinitas, sesuai dengan pernyataan Paechter (2006), kekuatan menunjukkan maskulinitas tidak hanya untuk laki-laki tetapi juga pada wanita. Berdasarkan uraian tersebut, maka dapat disimpulkan bahwa sabuk atau ikat pinggang Srikandi memiliki makna maskulinitas dilihat dari warna merah yang menandakan darah dan kekuatan api.

Srikandi adalah istri Arjuna yang cantik dan mahir memanah. Srikandi I dan Srikandi III menggunakan Endhong Panah, yaitu tempat untuk meletakkan anak panah dan biasa digunakan oleh ksatria atau prajurit (Nuraini, 2011). Panah Srikandi disebut sebagai panah Sengkali yang digunakan pada peperangan untuk melawan dan berhasil membunuh Bisma, (Soffiyana, 2015). Srikandi II menggunakan bentuk cringih-cringih atau lancip sebagai anak panahnya.

Berdasarkan penjelasan di atas, dapat dinyatakan bahwa panah menandakan maskulinitas, hal ini sesuai dengan pernyataan Mankayi (2008) senjata adalah suatu alat atau kunci dari maskulinitas. Orang sipil dengan seragam tentara dan senjata menjadi penentuan dominan dalam membentuk sisi maskulinitas.

Aksesoris ketiga kostum Srikandi yaitu sepatu, sepatu Srikandi I berwarna krem, Srikandi II berwarna olive green dan Srikandi III berwarna coklat tua Srikandi I mengenakan sepatu berwarna krem yang memiliki makna tertentu. Gading atau krem adalah warna yang canggih, gading adalah warna yang tenang, dengan beberapa kemurnian terkait dengan warna putih, bisa memberi kesan elegan dan tenang (Day, 2014). Ketika dikombinasikan dengan warna yang bersahaja seperti peach atau coklat, dapat menghasilkan kualitas yang bersahaja. Warna krem ada keterkaitan dengan warna putih, menurut Bleicher (2012), hitam dan warna putih adalah maskulin, sementara warna lainnya adalah warna feminin. Warna putih diartikan sebagai warna murni, serta warna realita, dan menandakan pemakaman pada budaya tertentu.

Srikandi II mengenakan sepatu boot hak tinggi warna hijau (olive green) menunjukkan sisi maskulinitas. Hal ini dapat dilihat dari makna konotasinya sebagai pelindung. Menurut Febrie (2014), sepatu boot memberi kesan maskulin, kuat, berani dan melindungi karena identik dengan para anggota militer. 
Srikandi III mengenakan sepatu boot berwarna coklat tua atau gelap. Warna coklat gelap menandakan maskulinitas, sesuai dengan pernyataan Ostberg (2012) yang menyatakan bahwa laki-laki menandakan maskulinitas dilihat dari gaya celana, seperti jeans, warna gelap. Menurut Kachtan dan Varda (2015), seragam militer identik dengan sepatu boot coklat, baret, kemeja yang diselipkan dan lain-lain. Semua ditujukan untuk menampilkan maskulinitas, kerapian, kekuatan dan pengendalian.

Srikandi, istri Arjuna ialah tokoh wayang yang digambarkan identik dengan kelelakiannya, dan dikenal sebagai prajurit atau pahlawan wanita (Hardjowirogo, 1989). Dewi Srikandi memiliki karakter tokoh sebagai seorang dewi yang kuat, yang mahir dalam memanah, dan ia sebagai ksatria pahlawan wanita dalam pewayangan Jawa (Solichin, 2016). Wanita di Indonesia yang memiliki karakter kuat, berani dan dapat menyelesaikan tugasnya dengan baik dijuluki Srikandi. Berdasarkan penjelasan di atas, maka dapat disimpulkan bahwa aksesoris Srikandi sebagai penguat maskulinitas. Hal ini dilihat dari kegunaan dan manfaatnya sesuai dengan makna dan mitosnya. Seperti panah sebagai alat untuk berperang. Hal ini sesuai dengan pernyataan Mankayi (2008) yang menyatakan bahwa senjata adalah suatu alat atau kunci dari maskulinitas.

\section{Kostum Srikandi sebagai Female Masculinity}

Analisis dengan konsep sintagmatik dan paradigmatik, menurut Barthes (1983) yang telah mengembangkan pandangan analisis de Saussure dengan sintagmatik dan paradigmatik, sintagme dan sistem sebagai dasar untuk menganalisis gejala kebudayaan yang dijadikan sebagai tanda. Sintagme merupakan suatu susunan yang didasari dengan hubungan sintagmatik. Susunan tersebut berhubungan erat dengan sebuah relasi. Hal ini dapat dilihat pada contoh dari sistem busana yang dijadikan sebagai tanda dan dianalisis melalui konsep sintagmatik. Dalam mengamati sistem busana, Barthes (1983) membedakan antara sintagme dan sistem. Jadi busana dapat dilihat sebagai cakupan perangkat unsur-unsur busana yang masing-masing mempunyai tempat tertentu pada tubuh manusia.

Tabel 3. Analisis Sintagmatik-Paradigmatik Tiga Kostum Srikandi

\begin{tabular}{|c|c|c|c|c|c|c|}
\hline Srikandi & $\begin{array}{l}\text { Tutup } \\
\text { Kepala }\end{array}$ & $\begin{array}{l}\text { Pelindung } \\
\text { Telinga }\end{array}$ & $\begin{array}{c}\text { Pelindung } \\
\text { Tubuh } \\
\text { Bagian } \\
\text { Atas } \\
\end{array}$ & $\begin{array}{c}\text { Pelindung } \\
\text { Tubuh } \\
\text { Bagian } \\
\text { Bawah } \\
\end{array}$ & $\begin{array}{l}\text { Alas } \\
\text { Kaki }\end{array}$ & Aksesoris \\
\hline \multirow{3}{*}{ I } & \multirow{3}{*}{ Mahkota } & \multirow{3}{*}{ Sumping } & \multirow{3}{*}{ Mekak } & & \multirow{3}{*}{ Sepatu } & Kalung \\
\hline & & & & & & Panah \\
\hline & & & & Rok & & Gelang \\
\hline \multirow{2}{*}{ II } & \multirow{2}{*}{ Mahkota } & \multirow{2}{*}{ Sumping } & \multirow{2}{*}{ Angkin } & Sabuk & \multirow{2}{*}{ Sepatu } & Kalung \\
\hline & & & & Celan & & Panah \\
\hline
\end{tabular}




\begin{tabular}{|c|c|c|c|c|c|c|}
\hline & & & & Panjang & & Gelang \\
\hline \multirow[b]{2}{*}{ III } & \multirow[b]{2}{*}{ Mahkota } & \multirow[b]{2}{*}{ Sumping } & \multirow[b]{2}{*}{ Baju } & Sabuk & \multirow[b]{2}{*}{ Sepatu } & Gelang \\
\hline & & & & $\begin{array}{c}\text { Celana } \\
\text { Tanggung }\end{array}$ & & Panah \\
\hline
\end{tabular}

Srikandi I, Srikandi II dan Srikandi III mengenakan mahkota berjamang cringih/lancip sebagai pelindung kepala. Mahkota dengan jamang yang dibuat dari anyaman bambu menunjukkan strata atau status sosial (Nuraini, 2011). Sikandi I dan Srikandi II mengenakan sumping cringih/lancip dominan warna merah (Pudak Sinumpet). Sumping warna merah dapat diganti dengan warna putih atau hitam yang memiliki makna kekuatan yang menandakan maskulinitas (Bleicher, 2012). Kostum Srikandi III mengenakan sumping cringih/lancip dominan warna putih dan coklat. Warna coklat dapat diganti dengan warna gelap yang menandakan kekuatan serta maskulinitas. Kekuatan menandakan maskulinitas, hal ini sesuai dengan pernyataan Paechter (2006), bahwa kekuatan menunjukkan maskulinitas tidak hanya untuk laki-laki tetapi juga pada wanita.

Pada bagian kalung Srikandi I mengenakan kalung wulan tumanggal dua susun merupakan aksesoris yang biasa dipakai oleh seorang ksatria. Kalung ini dapat diganti dengan kalung karset yang memiliki makna sama tapi fungsi yang berbeda. Kalung karset adalah kalung yang digunakan khusus pangeran yang halus atau gagah. Bentuk kalung ini seperti kail pancing, polos dan tajam (Nuraini,2011). Srikandi II mengenakan kalung berbentuk bulat berwarna merah merupakan aksesoris, kalung ini dapat diganti dengan warna kuning yang menandakan semangat dan juga optimis (Johnson, 2010).

Gelang yang digunakan pada Srikandi I dan Srikandi II adalah gelang calumpringan yang berbentuk lancip, dan dipakai oleh seorang ksatria. Gelang ini dapat digantikan gelang bentuk logam yang memiliki makna sama yaitu sebagai ricikan, namun berbeda fungsinya yang hanya digunakan oleh putra halus dan putra gagah (Nuraini, 2011). Gelang ini biasa digunakan oleh tokoh raja atau ksatria yang kedudukannya setara dengan raja merupakan filosofi dari seorang raja yang melindungi rakyatnya (Sunu, 2012). Kedudukan sebagai raja dan ksatria menandakan sisi maskulin pada Srikandi.Maskulinitas adalah apa yang dilakukan laki-laki dewasa dan anak laki-laki, misalnya laki-laki yang tertarik dengan kekuatan (Paechter, 2006).

Pakaian yang digunakan Srikandi I mengenakan pakaian Mekak warna merah dan manset lengan panjang sebagai pelindung tubuh bagian atas. Mekak yang digunakan dari bahan katun dapat diganti dengan bahan beludru yang lebih elegan. Warna merah dapat pula digantikan dengan warna hitam, sesuai dengan karakter Srikandi. Menurut Bleicher (2012), hitam dan warna putih adalah maskulin, sementara warna lainnya adalah warna feminin. Warna putih diartikan sebagai warna murni, serta warna realita, dan menandakan pemakaman pada budaya tertentu (Bleicher, 2012). Berdasarkan penjelasan tersebut, maka dapat disimpulkan bahwa mekak Srikandi menandakan maskulinitas. Srikandi II mengenakan Angkin warna olive green sebagai pelindung tubuh bagian atas.Angkin yang digunakan dari bahan katun dapat diganti dengan bahan beludru 
yang lebih elegan. Warna olive green dapat diganti dengan warna hijau gelap, agar maskulinitas Srikandi lebih terlihat. Menurut Ostberg (2012), laki-laki menandakan maskulinitas dilihat dari gaya celana, seperti jeans, dan warna gelap.

Srikandi III mengenakan baju warna coklat dan merah serta bentuk menyerupai baju laki-laki jaman dahulu. Warna coklat gelap menandakan maskulinitas, karena sesuai dengan pernyataan Ostberg (2012) yang menyatakan bahwa laki-laki menandakan maskulinitas dilihat dari gaya celana, seperti jeans, warna gelap. Menurut Kachtan dan Varda, (2015), seragam militer identik dengan sepatu boot coklat, baret, kemeja yang diselipkan dan lain-lain. Semua ditujukan untuk menampilkan maskulinitas, kerapian, kekuatan dan pengendalian.

Pada serangkaian pakaian terdapat bagian rok atau celana. Srikandi I mengenakan rok Keprajuritan puteri berwarna merah sebagai pelindung tubuh bagian bawah. Rok dapat diganti dengan celana panji-panji atau celana panjang. Celana memiliki konotasi yang berbeda dengan rok, namun dapat juga memiliki makna yang sama yaitu menunjukkan maskulinitas. Laki-laki menandakan maskulinitas dilihat dari gaya celana, seperti jeans, dan warna gelap (Ostberg, 2012). Srikandi II Celana panjang warna olive green sebagai pelindung tubuh bagian bawah.Celana panjang dapat digantikan dengan celana panji-panji. Celana Panji-panji ini dipakai semua jenis tari putera, baik tari putera halus maupun gagah, tetapi bisa juga dipakai untuk tari puteri tetapi yang khusus untuk peran atau tokoh puteri keprajuritan seperti Srikandi (Nuraini, 2011).

Srikandi III celana tanggung atau panji-panji, pelindung tubuh bagian bawah. Celana panji-panji dapat juga menggunakan beludru sebagai pengganti kain katun. Celana Panji-panji yaitu perlengkapan busana tari putera berbentuk celana sepanjang lutut yang terbuat dari bahan beludru dengan warna yang bermacam-macam (merah, hitam, ungu, dan sebagainya) dan diberi hiasan border manik-manik pada bagian bawahnya (Nuraini, 2011). Celana panji ini bisa juga dibuat dari bahan kain santung yang bermotif cinde (Nuraini, 2011). Adapun celana panji ini dipakai semua jenis tari putera, baik tari putera halus maupun gagah, tetapi bisa juga dipakai untuk tari puteri tetapi yang khusus untuk peran atau tokoh puteri keprajuritan seperti Srikandi.

Pakaian kostum Srikandi dibagian pinggang mengenakan sabuk atau ikat pinggang. Srikandi I dan Srikandi II mengenakan sabuk dengan model Slepe warna merah sebagai pelindung tubuh bagian bawah. Srikandi III mengenakan Sabuk Lonthon Cinde/Stagen yang digunakan sebagai ikat pinggang. Sabuk dapat diganti dengan epek timang yang memiliki fungsi sama walaupun makna berbeda. Epek timang yaitu berfungsi sebagai ikat pinggang terbuat dari beludru dengan disertai kancing yaitu timang (Nuraini, 2011).

Srikandi adalah seorang ksatria putri yang mahir memanah. Srikandi I, Srikandi II dan Srikandi III menggunakan senjata panah sengkali bentuk runcing atau lancip sebagai alat perang. Panah Srikandi menandakan maskulinitas, hal ini sesuai dengan pernyataan Mankayi (2008) yang menyatakan bahwa senjata adalah suatu alat atau kunci dari maskulinitas. 
Pada bagian kaki, Srikandi mengenakan sepatu. Srikandi I mengenakan sepatu hak tinggi polos warna krem sebagai alas kaki. Sepatu dengan model hak tinggi dengan warna krem dapat diganti dengan model sepatu boot warna coklat gelap yang memberikan makna kekuatan dan maskulin. Warna coklat gelap menandakan maskulinitas, sesuai dengan pernyataan Ostberg (2012) yang menyatakan bahwa laki-laki menandakan maskulinitas dilihat dari gaya celana, seperti jeans, warna gelap. Menurut Kachtan dan Varda (2015), seragam militer identik dengan sepatu boot coklat, baret, kemeja yang diselipkan dan lainlain.Semua ditujukan untuk menampilkan maskulinitas, kerapian, kekuatan dan pengendalian.

Srikandi II mengenakan sepatu boot dengan hak tinggi warna olive green digunakan sebagai alas kaki. Warna olive green yang dikenakan oleh Srikandi, dapat diganti dengan warna merah yang memiliki makna kekuatan dan api. Sesuai dengan pernyataan Plato dalam Kiefer (2003) bahwa warna merah memiliki arti api dan menyerupai darah. Warna merah menurut Johnson (2010), juga diartikan sebagai warna darah yang berhubungan dengan perang. Perang berarti kekuatan yang menandakan maskulinitas. Kekuatan menunjukkan maskulinitas yang tidak hanya untuk laki-laki tetapi juga pada wanita (Paechter, 2006). Pada kostum Srikandi III mengenakan sepatu boot dengan hak tinggi warna coklat gelap. Warna coklat gelap menandakan maskulinitas. Laki-laki menandakan maskulinitas dilihat dari gaya celana, seperti jeans, dan warna gelap (Ostberg, 2012).

Berdasarkan penjelasan di atas, maka dapat disimpulkan bahwa sistem berbusana Srikandi menandakan karakter wanita yang memiliki sisi maskulin. Hal ini dilihat dari busana Srikandi yang dapat diganti dengan busana lain, misalnya dari bahan atau busana lain yang masih memiliki makna maskulinitas. Selain itu, dapat juga diganti dengan warna lain yang menandakan maskulinitas sesuai dengan makna konotatif dan mitos. Peneliti menganalisis warna yang menandakan maskulinitas sesuai dengan makna warna maskulin yang telah dianalisis oleh para ahli sebelumnya, yang selajutnya dijadikan sebgai refernsi peneliti.

\section{Simpulan}

Berdasarkan hasil penelitian dari ketiga kostum Srikandi, maka dapat ditarik kesimpulan bahwa Srikandi adalah tokoh yang memiliki sifat maskulin diamati dari analisis warna, seperti warna hitam dan putih sesuai dengan pernyataan Bleicher (2012), hitam dan warna putih adalah maskulin, sementara warna lainnya adalah warna feminin. Warna putih sebagai warna murni, serta warna realita, dan menandakan pemakaman pada budaya tertentu. Johnson, (2010), menyatakan merah adalah warna darah yang berhubungan dengan perang. Perang berarti kekuatan yang menandakan maskulinitas. Warna gelap sesuai dengan pernyataan Ostberg (2012) yang menyatakan bahwa laki-laki menandakan maskulinitas dilihat dari gaya celana, seperti jeans, dan warna gelap. 
Makna denotasi dan konotasi serta makna mitos dari kostum juga aksesoris pendukung kostum, seperti ricikan (mahkota, kalung, gelang, sabuk dan panah) yang dihubungkan dengan sintagmatik dan paradigmatik, dan karakteristik yang umumnya dianggap maskulin, misalnya, kekuatan. Menurut Parvathi (2017) maskulinitas menggambarkan kekuatan, agresifitas dan kejantanan pada tubuh wanita. Soffiyana (2015) menyatakan, bahwa Srikandi merupakan wanita maskulin yang tangguh dan energetik, serta pemberani dan juga masih tetap cantik walaupun memiliki karakter pemberani, akan tetapi Srikandi tidak meninggalkan sisi femininnya sesuai dengan kodratnya sebagai wanita. Agresifitas, kepemimpinan, dan ketegasan tersebut,sesuai dengan pernyataan Mooka (2016) yang menyatakan bahwamaskulinitas wanita dilihat dari kinerja atau perilaku maskulin pada tubuh wanita yang karakteristik umumnya dianggap maskulin misalnya, menunjukkan kekuatan, keberanian, agresivitas, kepemimpinan, ketegasan, dominasi, dan kekerasan.

Untuk kedepannya diharapkan para akademisi dapat melakukan penelitian terhadap tokoh wayang wanita yang menunjukkan maskulinitas. Peneliti juga bisa mengungkap bagaimana makna kostum dan aksesoris yang dikenakan oleh tokoh tersebut.

\section{Ucapan Terima Kasih}

Peneliti mengucapkan banyak terimakasih kepada seluruh pihak yang memberi dukungan kepada peneliti agar segera menyelesaikan penelitian ini. Terima kasih kepada, semua pihak yang telah membantu demi terlaksananya penelitian ini.

\section{Daftar Pustaka}

Barthes, Roland. (1983). The Fashion System. London: University Of California. Barnard, Malcolm. (2011). Fashion Sebagai Komunikasi. Yogyakarta: Jalasutra.

Bleicher, Steven. (2012). Contemporary Color Theory and Use. Delmar, Cengage Learning: United States.

Budaya, Sekar Nusantara. (2011). Ricikan (Aksesoris Wayang Orang). Diakses pada tanggal 27 September 2018 pada pukul 13:36 WIB. http://sekarbudayanusantara.co.id/Wynk/?p=1073

Day, U. O. (2014). Website colour research, Issue: November.

Endraswara, Suwardi. (2005). Metode dan Teori Pengajaran Sastra. Yogyakarta: Buana Pustaka.

Febrie, Prissy Tjiabrata, dkk. (2014). Makna di Balik Penampilan Preman dan Perubahannya dalam Film Bioskop Indonesia di Tahun 1986-2014. Universitas Kristen Petra : Surabaya.

Halberstam, Judith. (1998). Female Masculinity. Durham and London: Duke University press.

Hajariah, Siti dan Briandana, Rizki. (2013). Gender and the Action Film: Questions of Female Heroism (Analysis of Female Masculinity of the Female Heroic Character). Jurnal Visi Komunikasi. Vol. 12 (2), page: 
Farah Nur Azizah, Yudha Wirawanda : Makna Female Masculinity dalam Kostum Wayang Srikandi Red Batik Solo

183-206.

Hardjowirogo. (1989). Sejarah Wayang Purwa. Jakarta: PN Balai Pustaka.

Husaini dan Purnomo. (2014). Metodologi Penelitian Sosial. Jakarta: PT Bumi Aksara.

Hyman, John. (2006). The Obyective Eye. The United States: The University of Chicago Press, Ltd., London.

Johnson, D. (2010). Color Psychology. Vol. 05, page: 1-10.

Kachtan, Dana., \& Varda Wasserman. (2015). (Un)dressing Masculinity: The Body as a Site of Ethno-Gendered Resistance. The University Road: Organization 2015. Vol. 22(3) Page: 390-417.

Kiefer, T., \& Nr, M. (2003). The History of Colors. University of Applied Sciences Offenburg

Kominfo. (2014). Direktorat Jendral Ekonomi Kreatif Berbasis Seni dan Budaya. Jakarta: Kementrian Komunikasi dan Informasi.

Kuruc, K. (2008). Fashion as communication: A semiotic analysis of fashion on "Sex and the City". Semiotica, Vol. 171, page: 193-214.

Mankayi, N. (2008). Masculinity, Sexuality and the Body of Male Soldiers. Pins, Vol. 36, page: $24-44$.

Mooka, Edward. (2016). An Analysis of Female Masculinity in Ousmane Sembene's God's Bits of Wood. Baraton Interdisciplinary Research Journal, Vol. 6, 171-177.

Nuraini, Indah. (2011). Tata Rias dan Busana Wayang Orang Gaya Surakarta. Yogyakarta: Institut Seni Indonesia.

Ostberg, J. (2012). Masculinity and fashion. Gender, Culture, and Consumer Behavior. Issue: July, page: 255-284.

Paechter, Carrie. (2006). Masculine Femininities/ Feminine Masculinities: Power, Identities and Gender. Gender and Education, Vol. 18 (3), page: $253-263$.

Parvathi. (2017). "Female Masculinity" in Dystopian Adolescent Fiction Suzanne Collins' Hunger Games Series. European Journal of Social Sciences Education and Research, Vol.10 Nr. 1. Page: 44-50.

Pujileksono, Sugeng. (2015). Metode Penelitian Komunikasi Kualitatif. Malang: Intrans Publishing.

Rakhmat, Jalaluddin. (2005). Metode Penelitian Komunikasi: Dilengkapi dengan Contoh Analistik Statistik. Bandung: PT Remaja Rosdakarya.

Rusdy, Sri Teddy. (2015). Semiotika dan Filsafat Wayang. Jakarta: Yayasan Kertagama.

Sain, Yuliyanah. (2018). Analisis Semiotika Pada Artikel "The Connotations of English Colour”. Fakultas Ilmu Budaya : Universitas Hasanuddin.

Sobur, Alex. (2016). Semiotika Komunikasi. Bandung: PT Remaja Rosdakarya.

Soffiyana, Naeli. (2015). Relasi Gender dan Kuasa dalam Penokohan Wayang (Srikandi dan Dewi Kunti dalam Perspektif Islam). Fakultas Ushuluddin dan Humaniora: Semarang.

Solichin. (2016). Tokoh Wayang Terkemuka. Jakarta: CV. Dedy Jaya.

Storey, John. (1996). Cultural Studies and the Study of Popular Culture: Theories and Methods. Edinburgh: The University of Georgia Press. 
Sunu, Naung Prasetyo. (2012). Komparasi Kostum Gathutkaca Dalam Wayang Wong Dan Wayang Purwa Gaya Yogyakarta. Jurusan Pendidikan Seni Tari Fakultas Bahasa Dan Seni: Universitas Negeri Yogyakarta.

Supriyono. (2008). Arti Motif Wayang : Jenis - Jenis Ikat Pinggang Wayang. Diakses pada tanggal 22 September 2018 pada pukul 20:11 WIB. https://wayangku.id/arti-motif-wayang-jenis-jenis-ikat-pinggangwayang/

Yulianti, Dewi Friska., Bajari, Atwar., \& Mulyana, Slamet. (2017). Representasi Maskulinitas Dalam Iklan Televisi Pond's Men \#Lelakimasakini (Analisis Semiotika Roland Barthes Terhadap Representasi Maskulinitas). Jurnal

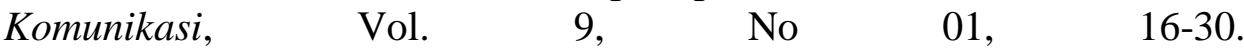
https://journal.untar.ac.id/index.php/komunikasi/article/view/180 